
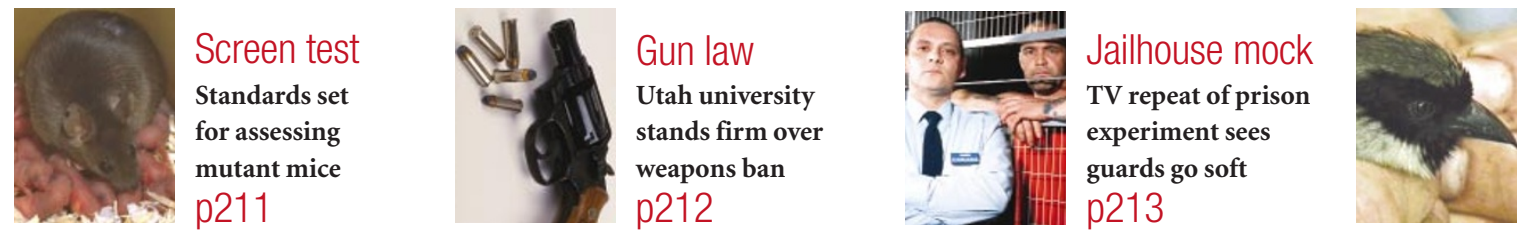

Love birds?

Feathers fail to fly as world's rarest birds choose celibacy p214

\section{Declan Butler, Paris}

Years of painstaking effort to boost scientific collaboration in the Middle East have been battered - but not yet destroyed - by the latest conflict in the region, researchers say.

War conditions in the region, supply shortages and restrictions on travel by Palestinian scientists have paralysed collaboration, and the escalation of conflict has polarized the views of researchers in both camps.

Nonetheless, many researchers are convinced that any let-up in the conflict may allow for a rapid revival in collaboration between Israeli and Arab scholars. There are also signs that the current crisis will galvanize international interest in promoting such collaboration.

In the optimism that followed the signing of the 1993 Oslo peace agreement, science emerged as one of the few areas where Arabs and Israelis could cooperate on common goals in a non-political setting. In this way, it could serve as a bridge for dialogue and mutual understanding (see Nature 375, 717-732; 1995).

But now, with the peace process in tatters, collaboration has been hit hard. Official scientific organizations in the region are under

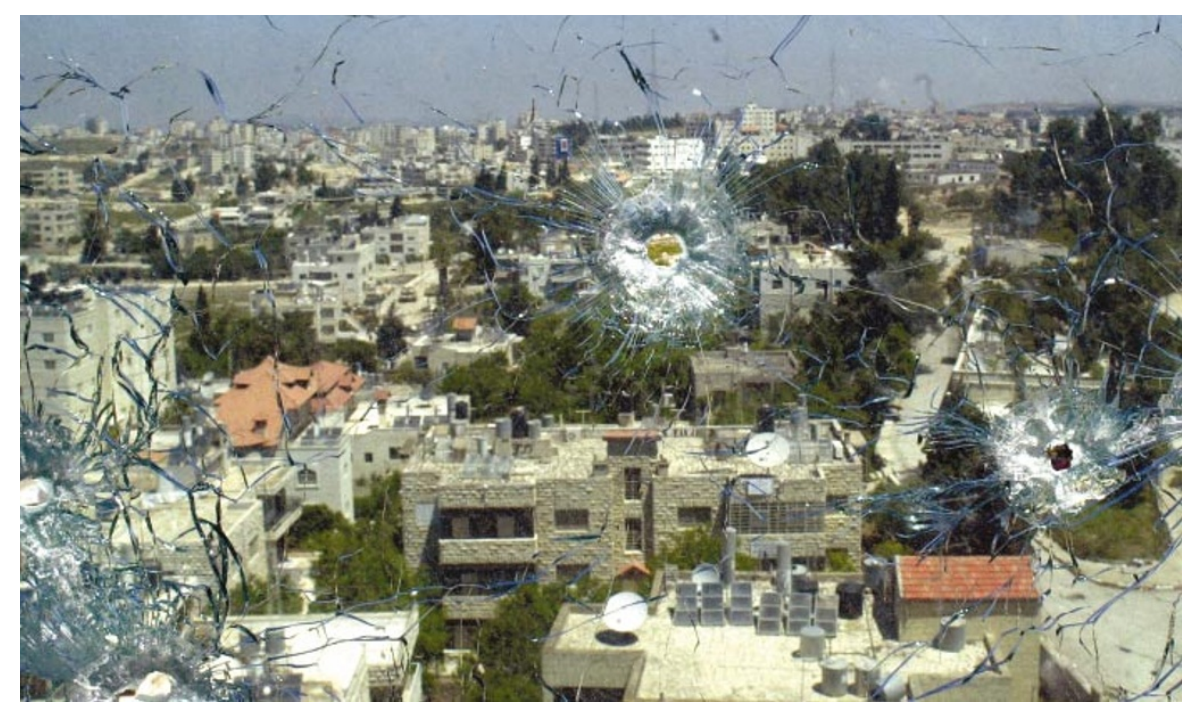

Shattered hopes: Israeli and Palestinian scientists must work to repair damage done by the conflict.

attack for their conspicuous public silence on the issues that matter most to researchers on both sides. Many observers argue that these organizations need to take a more courageous public stand if impetus is to be regained.

Palestinian scientists cite travel restric-

\title{
Plan hatched to double NSF budget
}

Geoff Brumfiel, Washington

The Science Committee of the US House of Representatives is leading a new charge to double the \$5-billion annual budget of the National Science Foundation (NSF) within five years.

Scientific societies are strongly backing a bill, passed last week by the committee with bipartisan support, that would recommend more money for the NSF, the largest sponsor of non-biomedical university research in the United States. A companion measure to the bill is being planned in the Senate.

The NSF has won plaudits from the Bush administration for its management skills, but this year's budget includes only a modest $5 \%$ funding increase (see Nature
415,565 ; 2002). "Recognition is nice, but success requires real money," says Sherwood Boehlert (Republican, New York), chair of the Science Committee.

If it is passed into law, the bill would recommend $15 \%$ increases in the NSF budget for each of the next five years. Actual increases are set each year by appropriations committees, which are likely to be influenced by such a law.

Congress has made statements supporting the doubling of funding for research, but only the National Institutes of Health, which supports biomedical research, has actually obtained the money. Now science lobbyists are hoping that the NSF can garner similar treatment. tions imposed by Israel as a major impediment to collaboration. These have become steadily stricter since the start of the second Palestinian uprising, or intifada, in September 2000. And since the occupation of the West Bank, movement for Palestinian researchers and students there has become almost impossible.

"The upper levels of Israeli universities were pretty much unwilling to use their political clout in pushing for freedom of movement," says Paul Scham, a researcher at the Harry S. Truman Research Institute for the Advancement of Peace at the Hebrew University of Jerusalem and the author of a study on Israeli/Arab research cooperation.

"Israeli scientists tend to distinguish between support for academic cooperation and ending frontier closures, which they consider a security matter. But Palestinians consider greater freedom of movement a prerequisite to more normal relations with Israeli academics," says Scham.

Israeli researchers, meanwhile, complain privately that their Palestinian colleagues have said nothing in public about the suicide bombings that provoked the occupation of the West Bank.

As Israeli tanks withdrew from the West Bank earlier this month, tensions between 
the Palestinian and Israeli science communities heightened further. Palestinian officials and Israeli peace activists claimed that damage done during the occupation had weakened the fledgling Palestinian research and education infrastructure.

The Palestine Academy of Science and Technology in Ramallah, for example, was damaged when Israeli troops used explosives to blast open doors before searching the building, says Imad Khatib, director general of the academy. Furniture was smashed, and files and office equipment were scattered on the floor, he adds.

$\mathrm{Al}$ Quds University claims that Israeli soldiers badly damaged laboratories and other buildings at its campuses in El Bireh and Ramallah. The university has asked the Israeli government and the international community to send fact-finding missions and to help rebuild its infrastructure. It has also pleaded for US $\$ 675,000$ of emergency aid, without which it says it will be unable to pay its 700 staff and may face closure.

Israeli officials were unavailable to comment on the specific allegations as Nature went to press. But the Israeli army has said it is taking allegations of vandalism seriously and will investigate them fully. The extent of the damage and the circumstances in which it was inflicted remain unclear. "It has been difficult to isolate and concentrate on specific aspects of the military operation," says Eva Illouz, a peace activist and researcher in sociology and anthropology at the Hebrew University. "News of the destruction of the research facilities went largely unnoticed."

Palestinian scientific leaders accuse the Israeli scientific community of being oblivious to their plight. Khatib, for example, complains that Israeli scientific leaders are "indifferent" to the damage at the Palestine Academy. Illouz counters that Israeli scientists are "disturbed" by reports of the destruction, but admits that there has been no public outcry because attitudes have hardened between Arab and Israeli scientists following the second intifada.

Dudy Tzfati, a geneticist at the Hebrew University of Jerusalem and one of the founders of the Alliance of Middle Eastern Scientists and Physicians, a body that is committed to promoting peace, nonetheless remains optimistic about the future. He predicts that the mutual trust created by contacts among scientists will endure, and that the international scientific community should renew its support for such cooperation.

Similarly, Nachum Finger, rector of Ben Gurion University, predicts that, on any sign of a return to normality, "the universities, the scholars, will be back to lead the rapprochement with the Palestinians".

\section{Warhead-saving arms pact gets lukewarm reception}

\section{Geoff Brumfiel, Washington}

American scientists have reacted with little enthusiasm to a new US-Russian nuclear arms pact, announced on 13 May, that would reduce the number of nuclear weapons deployed on each side but would take no action to destroy their warheads.

The three-page treaty, which will be signed by presidents George Bush and Vladimir Putin at a summit in Moscow next week, pledges to reduce the number of deployed nuclear weapons from 5,000-6,000 on each side to between 1,700 and 2,200 over the next 10 years.

But the plan would allow the decommissioned warheads to be kept in reserve rather than being destroyed — raising alarm about the possible security of the warheads, particularly in Russia. The freedom to keep the warheads was sought by the Bush administration, but it runs counter to the advice of many US scientists. In a 1997 study, the National Academy of Sciences called for the bilateral destruction of decommissioned warheads.

Scientists welcomed the fact that the two heads of state will actually sign a treaty - the Bush administration had originally proposed a less formal agreement — but lamented its lack of real content. On the day the treaty was announced, the Union of Concerned Scientists released a letter signed by seven prominent US physicists to both presidents, calling for a treaty that would destroy decommissioned warheads as quickly as possible.

"This treaty is certainly a step forward, but it leaves a lot to be desired," says Michael Levi, a physicist at the Washington-based Federation of American Scientists. Levi says that the agreement will strengthen proWestern elements in the Russian government. But he adds that, in storage, Russian warheads pose a significant threat. "If one of those warheads falls into terrorist hands, then we'll we wish that we had used our stored warheads as a bargaining chip to have them eliminated," he warns.

Wolfgang Panofsky, former director of the Stanford Linear Accelerator Center in California, and one of the seven who signed the letter, says he is disappointed that the treaty fails to address smaller tactical warheads, which, he says, are considered a significant threat to non-proliferation efforts. Nonetheless, he says, "the treaty should be applauded as a forward step".

www.ucsusa.org

\section{Computer revives Bamiyan Buddha}

\section{Quirin Schiermeier, Munich}

The giant statue of Buddha at Bamiyan in Afghanistan, one of two destroyed in March last year by the Taliban, will soon be reconstructed - electronically.

Researchers at the Swiss Federal Institute of Technology in Zurich are close to completing a three-dimensional computer model of the 2,000-year-old statue, using a set of high-resolution images taken in 1970 by Austrian cartographers.

"A high-accuracy computer model, which could be used as the basis for physical reconstruction, will be available by the end of the month," says Fabio Remondino, one of the scientists involved in the project.

But authorities warn that a full physical reconstruction is unlikely. Christian Manhart, an Asian specialist at the United Nations Educational, Scientific and Cultural Organization, says that rebuilding the statue, which stood nearly 55 metres tall, is neither realistic nor desirable.

The site should be left as it is and be protected as a memorial, similar to the concentration camp at Auschwitz or the memorial church in Berlin, Manhart says, as

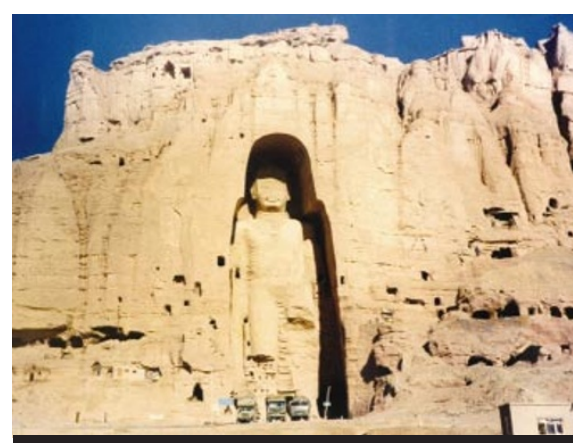

Lost treasure: Bamiyan's giant Buddha before the Taliban's act of destruction.

recommended by the 1964 International Charter for the Conservation and Restoration of Monuments and Sites.

Paul Bucherer-Dietschi, director of the Afghanistan Institute and Museum near Basel in Switzerland, is coordinating a feasibility study on possible reconstruction of the statue. He will meet with 40 other experts in Kabul this month to discuss the protection and restoration of Afghanistan's cultural heritage.

www.photogrammetry.ethz,ch/research/bamiyan 